\title{
Social media advertising efficiency on higher education programs
}

Higher education programs

\section{Eficiencia publicitaria de los medios sociales en programas de educación superior}

\author{
Rebeca Cordero-Gutiérrez \\ Faculty of Computing Science, Pontifical University of Salamanca, Salamanca, Spain \\ and School of Languages and Education, Nebrija University, Madrid, Spain, and \\ Eva Lahuerta-Otero \\ Department of Business Administration, Universidad de Salamanca, Salamanca, \\ Spain and IME Business School, Salamanca, Spain
}

\begin{abstract}
Purpose - The purpose of this study is to examine the different results and the level of success obtained with advertising campaigns developed on Facebook to promote postgraduate programs to create awareness and engagement.

Design/methodology/approach - This study combined the data envelopment analysis technique to measure advertising efficiency with multidimensional scaling (MDS) representation, thus offering alternatives for practitioners and organizations on how to evaluate social advertising performance.

Findings - Investments on social paid advertising are an affordable and effective way both to promote postgraduate programs and create engagement with prospective students. Facebook advertisements maximize visibility, which improves social and online positioning and encourages student recruitment.

Practical implications - Higher education institutions can efficiently promote their programs with a minimal social investment contributing to dissemination and engagement. Compared to other forms of traditional or digital advertising, social media ads can be efficient and affordable with wider segmentation and targeting options. Moreover, results are immediate and measurable and campaigns can be instantly modified to better suit the audience's requirements.
\end{abstract}

(C) Rebeca Cordero-Gutiérrez and Eva Lahuerta-Otero. Published in Spanish Journal of Marketing ESIC. Published by Emerald Publishing Limited. This article is published under the Creative Commons Attribution (CC BY 4.0) licence. Anyone may reproduce, distribute, translate and create derivative works of this article (for both commercial and non-commercial purposes), subject to full attribution to the original publication and authors. The full terms of this licence may be seen at http:// creativecommons.org/licences/by/4.0/legalcode

This work was supported by the Ministry of Economy and Competitiveness [grant number ECO2017-82107-R] and [grant RTC-2016-5315-6].

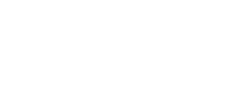


SJME

24,2

Originality/value - This study is unique as it offers a new, alternative way of measuring efficiency, in addition to the classic ratios of payment models in digital advertising that combine clicks and impressions, on a sector where there are few empirical studies. Moreover, it can be easily applied to many other sectors in public and private organizations.

Keywords Social media advertising, Facebook ads, Efficiency, Advertising efficiency Higher education, Postgraduate programs, Mixed-methods approach, DEA, MDS

Paper type Research paper

\section{Resumen}

Propósito - El objetivo de esta investigación es examinar los diferentes resultados y el nivel de éxito obtenido con las campañas publicitarias desarrolladas en Facebook para promover programas de postgrado que aumenten la notoriedad y la participación de los mismos.

Diseño/método/enfoque - Combinamos la técnica de análisis de envolvente de datos (DEA) para medir la eficiencia de la publicidad con la representación de escalado multidimensional (MDS), ofreciendo alternativas tanto a profesionales como a organizaciones sobre cómo evaluar el rendimiento de la publicidad social.

Hallazgos - Las inversiones en publicidad social pagada son una forma asequible y efectiva tanto para promover programas de postgrado como para crear un compromiso con los posibles estudiantes. Los anuncios en Facebook maximizan la visibilidad, lo que también mejora el posicionamiento social y en línea, fomentando la captación de estudiantes.

Implicaciones prácticas - Las instituciones de educación superior pueden promover eficazmente sus programas con una inversión social mínima que contribuya a la difusión y el engagement. En comparación con otras formas de publicidad tradicional o digital, los anuncios de los medios sociales pueden ser eficientes y asequibles, con una segmentación y opciones de orientación más amplias. Además, los resultados son inmediatos y cuantificables y las campañas pueden modificarse instantáneamente para adaptarse mejor a las necesidades del público objetivo.

Originalidad/valor - Esta investigación es única ya que ofrece una nueva y alternativa forma de medir la eficiencia, además de los ratios clásicos de los modelos de pago en la publicidad digital que combinan clics e impresiones, en un sector en el que hay pocos estudios empíricos. Además, puede aplicarse fácilmente a muchos otros sectores en organizaciones públicas y privadas.

Palabras clave Publicidad en medios sociales, Facebook ads, Eficiencia, Eficiencia publicitaria, Educación superior, Programas de postgrado, Enfoque de métodos mixtos, DEA, MDS

Tipo de artículo Trabajo de investigación

\section{Introduction}

Information communication technology tools and social network sites are central to people's personal lives as has been reflected by statistics, indicating that there were 2.82 billion social media users worldwide in 2019, 6.8 billion mobile phone users and the high usage of Web 2.0 technologies (Statista, 2019a, 2019b). Such tools also are increasingly incorporated in learning and teaching settings (Arrosagaray et al., 2019), especially because current generations of higher education students have grown up in environments dominated by the Internet and digital technologies. With their early exposure, they gained strong digital skills, and they use social media for common, daily tasks such as communication, seeking information, social interactions, shopping and education. For example, $88 \%$ of 18 - to 29 year-olds in the USA use some form of social media (Pew Research Center, 2018) and 85\% of Spaniards use social media daily (IAB Spain, 2019).

A challenge for higher education organizations then is to find ways to manage information efficiently to attract and motivate users to pursue higher education by incorporating and exploiting the functions available on social networking sites. As Stieglitz et al. (2018) posit the use of social media analytics requires discovering, collecting and preparing relevant data. The rapid expansion of the Internet, combined with the possibilities 
for independent, individualized education, have motivated universities and organizations to invest resources in developing online programs and promotional mechanisms (Ozkan and Koseler, 2009). For example, by adopting and integrating social network sites into their promotional strategies, public education institutions might overcome isolation or low student enrollment (Lim and Richardson, 2016) because the Internet and social network sites can establish participatory communities in which users and brands interact. Of note, $81 \%$ of Spaniards clicked on ads at least once in the last year (social media users between 16 and 30 years of age clicked more frequently) and 30\% agreed to share personal information to get personalized offers and promotions (IAB Spain, 2019). The more customers use, engage and interact with social media, the more information is generated for organizations to learn about those users and provide personalized advertising that suits their needs. Research by Heiberger and Harper (2008), Imlawi et al. (2015) and Rueda et al. (2017) specifically suggests a positive correlation between Facebook usage and student engagement at the university level.

Although organizations of various types are possibly aware of the power of social media, only $22.1 \%$ of Facebook pages have some kind of paid advertising. This percentage is very low compared with other forms of advertising, which could indicate that firms do not know how to exploit the opportunities of Facebook's information management for engagement and promotion (Islam and Rahman, 2017). With this research, we seek to specify the benefits of self-promotion through social media for prospective users and organizations. For example, the use of these informational tools enables cost and time savings (Malhotra and Peterson, 2001) because paid social advertising (e.g. Facebook Ads) supports personalization efforts that are likely to attract customers' attention. Thus, digital marketing expenditures represent $47 \%$ of total media ad spending worldwide and possibly account for half of total advertising expenditures by 2020 (eMarketer, 2019).

Although researchers investigate the impact of personalized ads issued through traditional media (Baek and Morimoto, 2012; Yu and Cude, 2009), websites (Awad and Krishnan, 2006; Bleier and Eisenbeiss, 2015; Ho and Bodoff, 2014) and mobile channels (Kim and Han, 2014; Xu, 2006), few studies consider the effects of personalized ads on Facebook (De Keyzer et al., 2015; Tucker, 2014) or their ability to attract users. Furthermore, questions remain regarding the use of social media technologies to support the teaching and professional practices of nonprofit institutions (Manca and Ranieri, 2016). Managing large amounts of social information effectively remains a challenge. To address these issues at least partially, we analyze the efficiency results of different Facebook advertising campaigns in the higher education sector.

According, Section 2 contains a literature review and theoretical framework used to evaluate the efficiency of social media advertising. Section 3 introduces the sample, methods, terminology and procedures used to obtain the results. In Section 4, we present the results and discuss our empirical analysis. Finally, in Section 5, we offer some conclusions and theoretical and practical implications for higher education organizations.

\section{Literature review}

\subsection{Social network sites and advertising acceptance}

To create a successful digital marketing strategy, brands, institutions and organizations must decide on a set of principles (Colvée, 2013). These principles include personalized marketing (i.e. based on segmentation and customization), intensive but non-intrusive marketing (i.e. reaching millions with minimal cost), interactive marketing (i.e. enabling bidirectional communication focused on customer participation, interaction, and involvement), emotional marketing (i.e. associating campaigns with customers' experiences, 
beliefs, emotions, dreams, and feelings) and measurable marketing (i.e. using tools to monitor and improve campaigns in real time). Effective uses of social media and paid social advertising can bring measurable benefits such as improved customer satisfaction, increased sales, better customer support, reduced marketing expenses and higher customer reach (Angel and Sexsmith, 2011; Askool and Nakata, 2011; Lahuerta-Otero and CorderoGutiérrez, 2016; Lahuerta-Otero et al., 2018; Stelzner, 2011).

According to uses-and-gratifications theory (Katz and Foulkes, 1962), people should be willing to expose themselves to social media to get benefits. These benefits generate positive aspects that directly influence their attitudes toward the medium. In social networks, users become integrated into a community of peers, some of which are huge (e.g. Facebook). Their resulting network relationships influence the users' opinions and behaviors because of the establishment of subjective norms. The benefits of using a medium, attitudes toward it and subjective norms together prompt different behaviors as has been demonstrated in research in various domains, including social networks research (Lam et al., 2007; Peslak et al., 2012; Cordero-Gutiérrez, 2018).

In turn, users might join a Facebook page to obtain updates, promotions or relevant information from the community (Lee and Hong, 2016). They also enjoy participating in discussions, belonging to a group and meeting new people, which gives them a favorable attitude (Celebi, 2015). They can interact with information by liking, commenting, tagging others or sharing it, which contributes to electronic word of mouth and expands the reach of the original content. Note that the users represent powerful and trustworthy sources of information (Chu and Kim, 2011). Thus, paid social advertising might offer an excellent, affordable way to create and maintain interactions of universities with former, current and prospective students.

Consistent with the roots of the perceived utility of advertising, personalized advertising matches customers' needs, as defined on the basis of demographic characteristics, interests or behaviors. When an ad is interesting to students, it provides useful information (i.e. benefits) and affects the way they respond, usually leading to acceptance. However, some users might not be interested in specific ads and try to prevent their exposure, resulting in ad avoidance (Speck and Elliott, 1997).

\subsection{Social network sites and advertising avoidance}

Proactive organizations should consider the perspective of users (e.g. whether they are receptive and willing to accept and implement changes) when integrating new technologies, including the use of paid social media advertising (Hamid et al., 2015). According to Tran (2017), there are different levels of ad avoidance on Facebook: affection (e.g. "I hate the ad"), cognition (e.g. ignore the ad) and behavior (e.g. install ad blocker software to block ad content). Moreover, users might be skeptical about some content or have a predisposition to mistrust advertising content (Aslam and Karjaluoto, 2017; Obermiller and Spangenberg, 1998; Pasadeos, 1990). Several factors can lead to ad avoidance such as clutter, intrusiveness, irritation and users' privacy concerns.

Clutter suggests that the existence of too many advertising messages makes it difficult to remember messages and brands (Cho and Cheon, 2004; Moe, 2006; Speck and Elliott, 1997). Ad clutter on the Internet can be operationalized as the number of all types of ads that appear on a single website. On social media, it refers to all types of ads, sponsored publications, ad videos and other forms of advertising that appear on a user's wall. Such excessiveness can lead to a perception that Facebook is solely an advertising medium for organizations, leading to ad avoidance (Cho and Cheon, 2004). 
According to Li et al. (2002), perceptions of intrusiveness and irritation can arise because of frequent interruptions or perceptions of information overload. According to Truong and Simmons (2010), users can distinguish between helpful (e.g. informative) and misleading (e.g. benefits are later found to be nonexistent) Internet ads. Moreover, online advertising improves product perceptions and credibility evaluations if it provides relevant content and is used correctly (Choi and Rifon, 2002; Shamdasani et al., 2001). Martí-Parreño et al. (2013) identify a negative relationship between irritation and attitudes toward mobile advertising (model was tested on teenagers, which will become prospective customers in social media contexts and will enroll in higher education centers in the future).

Online and mobile advertising that is relevant and tailored to consumers' needs (Tam and Ho, 2006) is less likely to irritate users. Perceived usefulness (Martí-Parreño et al., 2013) and informativeness (Wang et al., 2009) also reduce irritation.

Finally, privacy concerns refer to the anxiety that consumers feel when they worry that organizations might disclose their personal information (Cho and Hung, 2011). When navigating social media, users tend to have negative perceptions of advertising because they believe they are being targeted and tracked if they receive advertising without their permission (Lee and Hong, 2016; Smit et al., 2014; Youn and Shin, 2019). However, they recognize the importance of social media brand communications and interactivity and enjoy the benefits of promotions and offers (Cohen, 2012). Moreover, users navigating Facebook can choose whether they want to follow the updates of a brand page. If they agree, they can get special promotions, brand offers, discounts and information about events. Through this mechanism, brands can send commercial information to users without invading their personal space (Beauchamp, 2013), which may increase advertising efficiency.

\subsection{Social network sites and advertising efficiency}

An essential difference exists between paid search and paid social advertising. While paid search (e.g. Google AdWords) helps current and prospective customers find a business, paid social advertising (e.g. Facebook ads) makes it easier for a business to find customers (e.g. students). By targeting specific audiences, Facebook ads help businesses find the right customers those who are potentially interested in the higher education center by leveraging the big data available on Facebook (Shewan, 2017).

Paid social advertising focuses on finding targeted users rather than finding as many users as possible (as is a typical scope for traditional advertising platforms). Because Facebook users are still increasing (e.g. monthly active users increased from 2.27 million in the third quarter of 2018 to 2.44 million in the third quarter of 2019), and the potential audience is so large, organizations have a greater chance of finding the right customers (Facebook, 2019). This social platform offers a powerful, innovative and efficient targeting system that makes it easy and convenient for all types of organizations to connect with the most accurate customers (Andrews, 2017). Furthermore, Facebook continually improves its advertising platform by integrating information about users' consumption habits and preferred access devices (mostly smartphones). Accordingly, even with the many elements to consider when launching an advertising campaign (e.g. duration, budget, buying personas, segmentation criteria, objectives and expected outcomes), Facebook offers one of the most cost-effective advertising platforms (Shewan, 2017). The growth of its Facebook communities (i.e. Facebook, Instagram, Facebook Messenger and WhatsApp) has made Facebook a primary source of business leads (Andrews, 2017).

Although the cost of Facebook advertising has increased in recent years, the average cost-per-click (CPC) is $\$ 1.72$ (Shewan, 2017). In comparison, the average CPC for Google Ads across all industries in 2017 was $\$ 2.32$ (Irvine, 2018a, 2018b). Instead of focusing on the total 
amount spent on ads, marketers prefer to focus on CPC because they want to pay for actual actions rather than impressions. In this sense, CPC pricing is an important determinant of efficiency. If Facebook detects that an ad has greater relevance, it might lower the overall costs of the campaign, resulting in an optimal CPC (Gotter, 2017). These metrics are important to measure ad performance, but campaign success cannot be based solely on them because ad campaigns usually have goals beyond clicks (e.g. driving traffic to the organization's website).

To assess the efficiency of Facebook ads in promoting higher education postgraduate and masters' programs, our research questions ask:

RQ1. Are Facebook ads efficient when promoting higher education institutions' programs?

$R Q 2$. How can we identify efficient ads if the only variables the institution can control are the campaign budget and duration?

$R Q 3$. What effect do efficient ads have on social engagement in the context of higher education?

\section{Methods}

\subsection{Sample}

To assess the efficiency of social advertising for higher education empirically, we considered 45 valid Facebook ads by an organization that managed various training programs between 2015 and 2018 (e.g. postgraduate courses, master degrees) and only used Facebook for social paid promotion. This organization provided us with full access to their Facebook Ads platform to download the data from their campaigns on the condition of complete data anonymization.

The overall objective of the advertising campaigns was to increase traffic to the website. These ads combined image and text, and they were positioned on the right column of the page on mobile displays or linked sites. The ad segmentation approach relied on gender, age, language, location and interests. We can divide these ads into four quartiles, according to the levels of their efficiency. Specifically, quartile one represents ad efficiency rankings from $0 \%$ to $25 \%$, quartile two represents ad efficiency rankings from $25 \%$ to $50 \%$, and quartiles three and four represent ad efficiency rankings from $50 \%$ to $75 \%$ and $>75 \%$, respectively.

The sample of ads used in this research represents a total investment of $€ 11,395.06$, with more than 50 million impressions that reached nearly 10 million Facebook users (total reach $=$ 9,694,366 people) and generated more than 1 million ad clicks. We thus work with a sample that, though a priori small in relation to the number of all ads, is important for the volume of expenditures and the results obtained by such campaigns.

\subsection{Procedure}

To test the efficiency of paid social advertising in the higher education context, we followed a two-stage research approach. In the first stage, we calculated efficiency scores for the ads of our sample using the data envelopment analysis (DEA) technique. The second stage uses the multidimensional scaling methodology (MDS) to represent the ads in a consensus map.

3.2.1 First stage: Data envelopment analysis. The DEA technique is one of many statistical techniques used to estimate efficiency. This non-parametric, linear and programming-based technique is designed to measure the relative performance of decision- 
making units (DMUs) when the presence of multiple inputs and outputs pose difficulties for comparisons. It can transform a productive situation in which various resources generate multiple products into a single efficiency index. To determine the efficiency of each unit, the DEA technique estimates a reference frontier, reflecting the most productive (i.e. efficient) units in the sample. The inefficient units are located below the production frontier or above the cost frontier. Inefficient units are located "outside the frontier;" therefore, their level of inefficiency can be measured by the distance between their real situation and the corresponding production frontier (García et al., 1996). For our study, the units are different ads on Facebook.

The DEA technique is frequently applied because its estimates are based on ordinary least squares and consistent with the definition of the production function (Russell, 1985). Using the DEA technique with different outputs offers several further advantages too, in that it:

- enables a global analysis of each unit of analysis without a prior definition of a production function, which would require creating a unit to make a comparison (Shang and Sueyoshi, 1995);

- provides information on best practices for each inefficient unit;

- enables the inclusion of exogenous variables as uncontrollable inputs; and

- does not require assumptions of normality or the absence of heteroscedasticity.

However, DEA requires a positive correlation between input and output variables (Luo and Donthu, 2005). Table 1 shows the correlation matrix for our data set.

The efficiency of a DMU is measured as the maximum ratio of the linear combination of inputs and outputs. The maximum is obtained by selecting the optimal weights associated with these inputs and outputs. The highest possible efficiency reaches a value of 1 , indicating a point at the frontier, and therefore a technically efficient DMU.

We used an EMS software tool to determine the efficient and non-efficient units of analysis from among the 45 valid ads. The frontier analysis compares the relative efficiency of units (e.g. ads) when they perform similar tasks. These units use similar resources, referred to as inputs, to generate similar outputs. However, there might be significant differences in how each unit combines inputs (i.e. duration and amount spent on the ad) to produce outputs. Using this analysis, we obtain a comprehensive efficiency assessment by identifying units that make the best use of their resources, rated as 100\% efficient, whereas inefficient units earn lower scores. Moreover, this analysis shows the amount that inefficient units need to reduce their inputs or increase their outputs to become efficient. Specifically,

\begin{tabular}{lccccccc}
\hline Variable & $\mathrm{D}$ & $\mathrm{AS}$ & $\mathrm{R}$ & $\mathrm{I}$ & $\mathrm{C}$ & $\mathrm{RP}$ & $\mathrm{IP}$ \\
\hline Duration (D) & - & & & & & \\
Amount spent (AS) & $0.305^{*}$ & - & & & & \\
Reach (R) & 0.237 & $0.832^{* *}$ & - & & & \\
Impressions (I) & 0.200 & $0.842^{* *}$ & $0.907^{* *}$ & - & & & \\
Clicks (C) & 0.133 & $0.692^{* *}$ & $0.757^{* *}$ & $0.932^{* * *}$ & - & & \\
Reactions to the publication (RP) & 0.087 & 0.216 & $0.325^{*}$ & 0.175 & -0.060 & - & \\
Post engagement (PE) & 0.120 & $0.678^{* *}$ & $0.743^{* *}$ & $0.924^{* * *}$ & $0.988^{* *}$ & -0.069 & -
\end{tabular}

Notes: $* p<0.05 ; * * p<0.01$

Table 1. Correlation matrix 
we used the following variables as inputs and outputs to calculate the DEA index of the ad sample:

- (D) Duration (input): duration of the ad in days;

- (AS) Amount spent (input): total amount spent in euros;

- (R) Reach (output): number of people who have seen the ad at least once;

- Impressions (output): number of times the ad has been shown on the screen;

- (C) Clicks (output): number of clicks on the ad;

- (RP) Reactions to the publication (output): number of reactions in the ad. The reaction button in an ad enables people to share different feelings about the content with six different animated emoticons: love, haha (funny), wow (amazing), sad, angry, and like; and

- (PE) Post engagement (output): total number of actions that people take involving the ad, such as reacting to, commenting on, or sharing the ad; claiming an offer; viewing a photo or video; or clicking on a link.

3.2.2 Second stage: Multidimensional scaling methodology. After efficiency analysis, we graphically represented the units of analysis to determine the primary characteristics of our data matrix and the variables that best reflect these characteristics. To achieve this objective, an MDS technique was used in IBM SPSS. This technique represents the similarities and differences between several elements according to the distance between variables. The MDS produces a consensus map of units based on an underlying variable structure.

Similarities between the structures of individuals are visible through the proximity of the points represented. To calculate these dissimilarities, we selected the measure of the Euclidean distance. If two ads (cases) appear near each other, it is because they share similar information; however, they are positioned far from each other if their information is dissimilar.

We can project the variables from the original data matrix onto the same consensus map using the Co-Plot methodology. The coordinates of the variable positions are estimated using a series of linear regressions, whereby each variable is a dependent variable, and the coordinates of the four dimensions that place the ads on the map are explanatory variables. In this manner, we explain the extent to which the value considered by a given variable for a given ad is associated with the position in the space of the point that represents that ad. Using this approach, we can affirm that each quadrant groups ads with a similar underlying structure. The consensus map obtained with the MDS methodology provides a graphical representation of the underlying structural characteristics of the advertisements data set.

\section{Results and discussion}

After the efficiency analysis, a total of nine efficient ads were obtained from those analyzed in the sample, representing $20 \%$ of the cases. Moreover, five cases obtained high efficiency with values of $>80 \%$. In comparison, $44.44 \%$ of the ads analyzed did not achieve an efficiency of at least $50 \%$, and the lowest value of the sample earned an efficiency score of only $3.41 \%$.

According to MDS, the most accurate way to project the cases was on a four-dimensional map. To analyze the goodness-of-fit of our model, we used Kruskal's Stress 1 level, which measures the level of conformity between the original differences and the distances 
calculated from the map. It indicated a value of $1.067 \%$, an excellent fit level according to Kruskal's (1964) approach.

Figure 1 shows dimensions one and three, which best reflect the representation of the sample. This map presents the 45 ads that were analyzed and divided into quartiles according to the score received via the efficiency analysis obtained with the DEA technique. It also represents five original variables obtained using the Co-Plot methodology through their respective regressions.

The goodness of the R-square adjustment of the regressions indicates sufficient explanatory power to interpret the map. Table 2 shows the regression results.

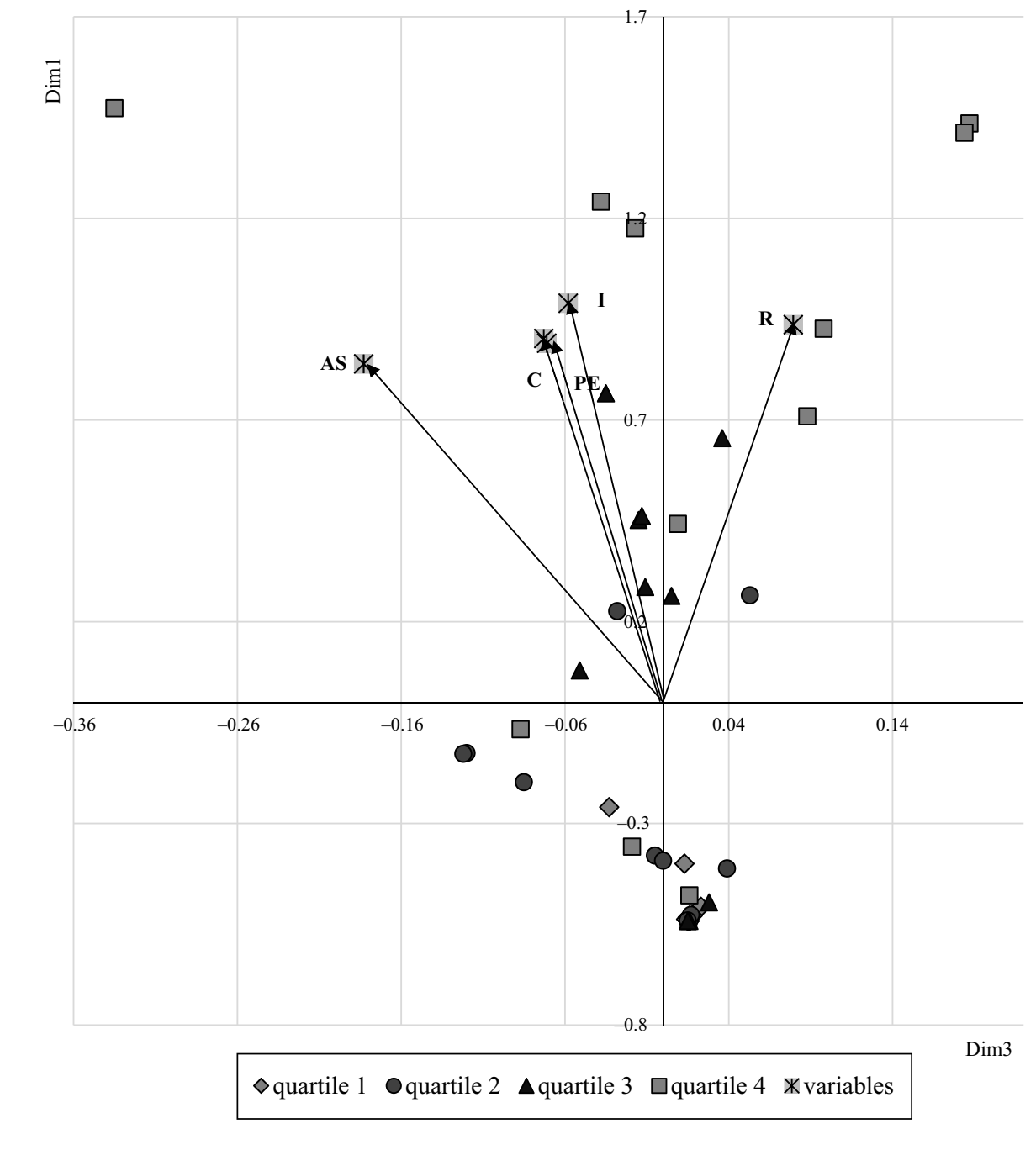

Notes: $\mathrm{C}=$ clicks $; \mathrm{I}=$ impressions $; \mathrm{R}=$ reach $; \mathrm{AS}=$ amount spent $\mathrm{PE}=$ post engagement

\section{Higher education programs}

Figure 1. Multidimensional scaling methodology (MDS) results 


\begin{tabular}{|c|c|c|c|c|c|c|c|}
\hline $\begin{array}{l}\text { SJME } \\
24,2\end{array}$ & Variable & $\begin{array}{l}\text { Adjusted } \\
R^{2}(\%)\end{array}$ & $\mathrm{F}(\operatorname{sig})$ & $\begin{array}{c}\text { Dim. } 1 \\
\text { Standardize } \\
\text { beta (sig) }\end{array}$ & $\begin{array}{c}\text { Dim. } 2 \\
\text { Standardize } \\
\text { beta (sig) }\end{array}$ & $\begin{array}{c}\text { Dim. } 3 \\
\text { Standardize } \\
\text { beta (sig) }\end{array}$ & $\begin{array}{c}\text { Dim. } 4 \\
\text { Standardize } \\
\text { beta (sig) }\end{array}$ \\
\hline \multirow{4}{*}{256} & Duration & 2.3 & $1.264(0.300)$ & $0.207(0.172)$ & $0.184(0.225)$ & $-0.103(0.495)$ & $-0.160(0.291)$ \\
\hline & Amount spent & 74.7 & $33.471(0)$ & $0.839(0)$ & $0.174(0.027)$ & $-0.183(0.021)$ & $-0.048(0.528)$ \\
\hline & Reach & 92.9 & $144.096(0)$ & $0.936(0)$ & $0.176(0)$ & $0.079(0.056)$ & $-0.147(0.001)$ \\
\hline & Impressions & 99.4 & $1735.03(0)$ & $0.989(0)$ & $-0.110(0)$ & $-0.058(0)$ & $-0.003(0.832)$ \\
\hline \multirow{4}{*}{$\begin{array}{l}\text { Table } 2 \text {. } \\
\text { Regression results }\end{array}$} & Clicks & 93.1 & $148.701(0)$ & $0.902(0)$ & $-0.341(0)$ & $-0.073(0.073)$ & $-0.031(0.433)$ \\
\hline & $\begin{array}{l}\text { publication } \\
\text { Post }\end{array}$ & 10.3 & $2.261(0.080)$ & $0.215(0.140)$ & $0.291(0.048)$ & $0.158(0.276)$ & $-0.169(0.244)$ \\
\hline & engagement & 92.2 & $127.944(0)$ & $0.890(0)$ & $-0.353(0)$ & $-0.071(0.103)$ & $-0.032(0.461)$ \\
\hline & \multicolumn{7}{|c|}{ Note: sig = significance level } \\
\hline
\end{tabular}

In Figure 1, the points of the variables are connected to the origin of the axes of the map using a vector, which makes it possible to understand the information collected by each dimension. The longer the vector of a variable, the better it is represented by the factorial planes. The angle between the vector and the dimension shows the relevance of the characteristics of a variable on the map. A dimension is strongly related to the variable when the angle between them is acute. If two endpoints of the vector are next to each other or very close, the associated variables transmit similar information (e.g. variables V1 or clicks and V5 or interaction of the user with the ad). We included V5 as an additional measure of efficiency because it reflects whether users actively engaged with an ad by liking, commenting or sharing it.

In Figure 1, we note that dimension three is primarily related to the number of impressions (I), the reach of the ad (R), the number of clicks (C) and the interaction or post engagement (PE) of the user with the ad. However, the only variable that is significantly related to dimension one is the amount spent (AS). In relation to the position of the ads on the map, we observe that dimension three perfectly divides the efficient ads (i.e. upper part) from the inefficient ads (i.e. lower part), except in cases 4 and 7 (i.e. squares at the top of dimension three).

Some efficient ad cases, such as 11, 14, 15, 23 and 31, appear at the bottom of Figure 1. These ads have special characteristics; they refer to campaigns for short courses in a specific field and with a limited audience. These characteristics are probably the reason they do not fit the efficiency patterns of other cases on the superior part of dimension three on the map.

\section{Conclusions}

\subsection{Theoretical implications}

This study offers alternative criteria to measure the efficiency of social media advertising platforms. Advertising on most media channels (e.g. television, radio and newspapers) possibly will be bought digitally in the future as the analog and online worlds merge; therefore, it is important to find new measures that offer a conjoint picture of the performance of an advertising campaign based on more than expenditures and clicks.

The DEA technique can measure efficiency according to an efficiency frontier, established by a set of observations, without the estimation of any production function, i.e. without the need to know any form of the functional relationship between inputs and outputs. The obvious advantage of the DEA technique is the degree of flexibility it provides 
and the absence of value judgments by the researcher regarding the relative importance of each variable in determining the efficiency of a DMU.

Moreover, digital ads cannot be effective if they are "viewed" by a non-human bot, resulting in an impression or a fraudulent click. The Association of National Advertisers ( $>1,000$ organizations with 15,000 brands that collectively spend or support $>\$ 250$ billion in marketing and advertising annually) publishes a yearly report showing that advertisers waste huge amounts of money through fraudulent ad impressions that improve their clickthrough rate (CTR) but do not constitute a real measure for engagement or efficiency. Fraud losses for 2019 were estimated to be $\$ 5.8$ billion globally (ANA, 2019).

Consequently, many organizations such as banks, hospitals, airlines, government departments and local authorities are starting to use the DEA technique to improve resource allocation, identify the best and worst practices and monitor efficiency changes over time. Digital advertising is about to dominate the way organizations communicate with their customers; this study offers recommendations for these advertisers to enhance their target setting and performance measurement.

\subsection{Managerial implications}

Advertisers and agencies should examine factors beyond CTR (which might be partially fraudulent) and ask how efficiently they are reaching their intended audiences. The use of a technique such as DEA provides useful information to improve ad efficiency in organizations because it facilitates the determination of the optimal allocation of organizational resources to obtain efficient results. In addition, it enables organizations to learn which decisions or actions have been unsuccessful and change their advertising strategies.

The majority of works that analyze advertising efficiency use CTR as the primary measure of efficiency. This ratio in isolation might not reflect the outcomes of institutions' advertising actions though because it does not compare ads and only considers two variables. We present several variables that reflect different dimensions of the advertising undertaken by educational institutions in reality. Moreover, the use of the DEA technique combines crossed information from different ads, which provides a global, rather than partial, view of the outcomes of ads within a campaign.

We find that efficient ads evoke a higher volume of clicks, impressions and reach. Thus, the content of ads that are considered efficient have a higher diffusion, which exponentially increases the potential for attracting students to different training programs promoted through Facebook. In addition, these ads promote interactions with the content, resulting in greater ad involvement among prospective students. This result indirectly increases the organic positioning of the organization's fan page on Facebook and thus of the organization's primary website, which is the destination of clicks on the ads.

Another noteworthy aspect is the amount spent on the execution of the ads. Although more efficient ads have higher expenditures in absolute terms, they have lower costs in relative terms. Thus, they generate greater results for visualization, diffusion and actions taken by the users, which implies greater involvement with the organization. Organizations that do not make a minimal investment in advertising are not exploiting the full potential of information management offered by social network advertising platforms such as Facebook Ads. Therefore, adequate investment in social network advertising platforms reinforces the advertising and promotion results, improving the results for nonprofit organizations by increasing their visibility and the possibility of attracting new users and prospective customers. 
This research enables us to make recommendations to the institutions responsible for higher education training programs such that they can effectively reallocate resources. Such efforts are especially important for nonprofit organizations, for which advertising investment resources tend to be very scarce. Digital advertising is a big opportunity for most advertisers in higher education and getting the reach right is the foundation of any well-designed, well-executed digital media plan. Higher education organizations should prioritize efficiency, and not just make an impression on the right audience. The difference between advertising effectiveness and efficiency is understanding that building a brand requires making a lasting emotional connection to justify a premium in the mind of the consumer, especially in higher education.

\subsection{Limitations and future research}

Although this study provides several contributions to existing research, it is subject to limitations. First, the sample used is small in terms of the number of ads. An extension of the sample may yield more robust results and reinforce the conclusions. Second, the variables selected to perform DEA analysis are crucial; new variables could be added to explain the efficiency patterns of the ads analyzed. Some promising variables might reflect the characteristics of the organization that manages the ads or the websites or fan pages that refer directly to the higher education institution.

Continued research might replicate this study with other types of nonprofit and for-profit organizations to check whether the efficiency patterns are similar. The individual characteristics of different types of organizations might lead to different results. Further research would make it possible to design and adapt promotion and dissemination strategies on social media, depending on the type of organization. Other experiments might include different advertising options for the same promotional goal to determine the best options for each type. Finally, future work might propose causal relationships between the variables that determine efficiency and other variables at the organizational and formative level to facilitate conclusions that provide a better understanding of the motivations and ambitions of prospective customers.

\section{References}

ANA (2019), "Bot baseline 2016-2017. Fraud in digital advertising”, available at: https://cdn2. hubspot.net/hubfs/3400937/2018-2019\%20Bot\%20Baseline\% 20Report\%20EXECUTIVE $\%$ 20SUMMARY.pdf

Andrews, M. (2017), "Why Facebook ads will make you successful in 2017 and Beyond”, available at: https://blog.hubspot.com/marketing/facebook-ads-successful-2017 (accessed 1 November 2018).

Angel, R. and Sexsmith, J. (2011), "Social networking: the corporate value proposition", Available at: htttp://iveybusinessjournal.com/topics/leadership/social-networking-the-corporate-valueproposition\#.VL90JUeG840 (accessed 5 October 2018).

Arrosagaray, M., González-Peiteado, M., Pino-Juste, M. and Rodríguez López, B. (2019), “A comparative study of Spanish adult students' attitudes to ICT in classroom, blended and distance language learning modes", Computers and Education.

Askool, S. and Nakata, K. (2011), "A conceptual model for acceptance of social CRM systems based on a scoping study", AI and Society, Vol. 26 No. 3, pp. 205-220.

Aslam, B. and Karjaluoto, H. (2017), "Digital advertising around paid spaces, E-advertising industry's revenue engine: a review and research agenda", Telematics and Informatics, Vol. 34 No. 8, pp. 1650-1662. 
Awad, N.F. and Krishnan, M.S. (2006), "The personalization privacy paradox: an empirical evaluation of information transparency and the willingness to be profiled online for personalization", MIS Quarterly, Vol. 30 No. 1, pp. 13-28.

Baek, T.H. and Morimoto, M. (2012), "Stay away from me", Journal of Advertising, Vol. 41 No. 1, pp. 59-76.

Beauchamp, M.B. (2013), “Don't invade my personal space: Facebook's advertising dilemma”, Journal of Applied Business Research (Jabr), Vol. 29 No. 1, p. 91.

Bleier, A. and Eisenbeiss, M. (2015), "The importance of trust for personalized online advertising", Journal of Retailing, Vol. 91 No. 3, pp. 390-409.

Celebi, S.I. (2015), "How do motives affect attitudes and behaviors toward internet advertising and Facebook advertising?”, Computers in Human Behavior, Vol. 51, pp. 312-324.

Cho, C.H. and Cheon, H.J. (2004), "Why do people avoid advertising on the internet?", Journal of Advertising, Vol. 33 No. 4, pp. 89-97.

Cho, V. and Hung, H. (2011), "The effectiveness of short message service for communication with concerns of privacy protection and conflict avoidance", Journal of Computer-Mediated Communication, Vol. 16 No. 2, pp. 250-270.

Choi, S.M. and Rifon, N.J. (2002), "Antecedents and consequences of web advertising credibility: a study of consumer response to banner ads", Journal of Interactive Advertising, Vol. 3 No. 1.

Chu, S.-C. and Kim, Y. (2011), "Determinants of consumer engagement in electronic word-of-mouth (eWOM) in social networking sites", International Journal of Advertising, Vol. 30 No. 1, pp. 47-75.

Cohen, D. (2012), "Brands, maintain a Facebook page, but don't bother me", available at: www. allfacebook.com/facebook-page-consumers-2012-02 (accessed 7 October 2018).

Colvée, J.L. (2013), Estrategias de Marketing Digital Para Pymes, Valencia: Anetcom.

Cordero-Gutiérrez, R. (2018), "Redes sociales horizontales y su impacto en el ámbito empresarial y social", Tesis doctoral. Universidad de Salamanca.

eMarketer (2019), "Digital ad spending worldwide, 2017-2022", www.emarketer.com/content/ emarketer-total-media-ad-spending-worldwide-will-rise-7-4-in-2018 (accessed 29 November 2019).

Facebook (2019), "Facebook Q3 2019 results", available at: https:/s21.q4cdn.com/399680738/files/ doc_financials/2019/q3/Q3-2019-Earnings-Presentation.pdf (accessed 29 November 2019).

García, F., Marcuello, C., Serrano, D., y. and Urbina, O. (1996), "Evaluación de la eficiencia en centros de atención primaria. Una aplicación del análisis envolvente de datos", Rev Esp Salud Publica, Vol. 70, pp. 211-220.

Gotter, A. (2017), "The complete resource to understanding facebook ads cost - 2017 benchmarks!", available at: https://adespresso.com/blog/facebook-ads-cost/ (accessed 19 October 2018).

Hamid, S., Waycott, J., Kurnia, S. and Chang, S. (2015), "Understanding students' perceptions of the benefits of online social networking use for teaching and learning", The Internet and Higher Education, Vol. 26 No. 26, pp. 1-9.

Heiberger, G. and Harper, R. (2008), "Have you Facebooked Astin lately? Using technology to increase student involvement", in Junco R. and Timm, D.M. (Eds), Using Emerging Technologies to Enhance Student Engagement: New Directions for Student Services, pp. 19-35, San Francisco, CA: Jossey-Bass.

Ho, S.Y. and Bodoff, D. (2014), "The effects of web personalization on user attitude and behavior: an integration of the elaboration likelihood model and consumer search theory", MIS Quarterly, Vol. 38 No. 2, pp. 497-A10.

IAB Spain (2019), "Estudio anual de redes sociales 2019", available at: https://iabspain.es/estudio/ estudio-anual-de-redes-sociales-2019/ (accessed 29 November 2019). 
Imlawi, J., Gregg, D. and Karimi, J. (2015), "Student engagement in course-based social networks: the impact of instructor credibility and use of communication", Computers and Education, Vol. 88, pp. 84-96.

Irvine, M. (2018a), "Facebook ad benchmarks for YOUR industry [new data]", available at: www. wordstream.com/blog/ws/2017/02/28/facebook-advertising-benchmarks (accessed 15 October 2018).

Irvine, M. (2018b), “Google ads benchmarks for YOUR industry [updated!]", available at: www. wordstream.com/blog/ws/2016/02/29/google-adwords-industry-benchmarks (accessed 15 October 2018).

Islam, J.U. and Rahman, Z. (2017), “The impact of online Brand community characteristics on customer engagement: an application of stimulus-organism-response paradigm", Telematics and Informatics, Vol. 34 No. 4, pp. 96-109.

Katz, E. and Foulkes, D. (1962), "On the use of the mass media as 'escape': clarification of a concept", Public Opinion Quarterly, Vol. 26 No. 3, pp. 377-388.

De Keyzer, F., Dens, N. and De Pelsmacker, P. (2015), "Is this for me? How consumers respond to personalized advertising on social network sites", Journal of Interactive Advertising, Vol. 15 No. 2, pp. 124-134.

Kim, Y.J. and Han, J.Y. (2014), "Why smartphone advertising attracts customers: a model of web advertising, flow, and personalization", Computers in Human Behavior , Vol. 33, pp. 256-269.

Kruskal, J.B. (1964), "Nonmetric multidimensional scaling: a numerical method”, Psychometrika, Vol. 29 No. 2, pp. 115-129.

Lahuerta-Otero, E. and Cordero-Gutiérrez, R. (2016), "Looking for the perfect tweet. The use of data mining techniques to find influencers on twitter", Computers in Human Behavior, Vol. 64, pp. 575-583.

Lahuerta-Otero, E., Cordero-Gutiérrez, R. and de la Prieta-Pintado, F. (2018), "Retweet or like? That is the question", Online Information Review, Vol. 42 No. 5, pp. 562-578.

Lam, T., Cho, V. and Qu, H. (2007), "A study of hotel employee behavioral intentions towards adoption of information technology", International Journal of Hospitality Management, Vol. 26 No. 1, pp. $49-65$.

Lee, J. and Hong, I.B. (2016), "Predicting positive user responses to social media advertising: the roles of emotional appeal, informativeness, and creativity", International Journal of Information Management, Vol. 36 No. 3, pp. 360-373.

Li, H., Edwards, S.M. and Lee, J.H. (2002), "Measuring the intrusiveness of advertisements: Scale development and validation", Journal of Advertising, Vol. 31 No. 2, pp. 37-47.

Lim, J. and Richardson, J.C. (2016), "Exploring the effects of students' social networking experience on social presence and perceptions of using SNSs for educational purposes", The Internet and Higher Education, Vol. 29, pp. 31-39.

Luo, X. and Donthu, N. (2005), "Assessing advertising media spending inefficiencies in generating sales", Journal of Business Research, Vol. 58 No. 1, pp. 28-36.

Malhotra, N.K. and Peterson, M. (2001), "Marketing research in the new millennium: emerging issues and trends", Marketing Intelligence and Planning, Vol. 19 No. 4, pp. 216-235.

Manca, S. and Ranieri, M. (2016), "Yes for sharing, no for teaching!: social media in academic practices", The Internet and Higher Education, Vol. 29, pp. 63-74.

Martí-Parreño, J., Sanz-Blas, S., Ruiz-Mafé, C. and Aldás-Manzano, J. (2013), “Key factors of teenagers' mobile advertising acceptance", Industrial Management and Data Systems, Vol. 113 No. 5, pp. $732-749$.

Moe, W.W. (2006), “A field experiment to assess the interruption effect of pop-up promotions”, Journal of Interactive Marketing, Vol. 20 No. 1, pp. 34-44. 
Obermiller, C. and Spangenberg, E.R. (1998), "Development of a scale to measure consumer skepticism toward advertising", Journal of Consumer Psychology, Vol. 7 No. 2, pp. 159-186.

Ozkan, S. and Koseler, R. (2009), "Multi-dimensional students' evaluation of e-learning systems in the higher education context: an empirical investigation", Computers and Education, Vol. 53 No. 4, pp. 1285-1296.

Pasadeos, Y. (1990), "Perceived informativeness of and irritation with local advertising", Journalism Quarterly, Vol. 67 No. 1, pp. 35-39.

Peslak, A., Ceccucci, W. and Sendall, P. (2012), "An empirical study of social networking behavior using theory of reasoned action”, Journal of Information Systems Applied Research, Vol. 5 No. 3, p. 12.

Pew Research Center (2018), "Social media use in 2018", Available at: www.pewresearch.org/internet/ wp-content/uploads/sites/9/2018/02/PI_2018.03.01_Social-Media_FINAL.pdf

Rueda, L., Benitez, J. and Braojos, J. (2017), "From traditional education technologies to student satisfaction in management education: a theory of the role of social media applications", Information and Management, Vol. 54 No. 8, pp. 1059-1071.

Russell, R.R. (1985), "Measures of technical efficiency", Journal of Economy Theory, No. 25, pp. 109-126.

Shamdasani, P.N., Stanaland, A.J.S. and Tan, J. (2001), "Location, location, location: insights for advertising placement on the web", Journal of Advertising Research, Vol. 41 No. 4, pp. 7-21.

Shang, J. and Sueyoshi, T. (1995), "A unified framework for the selection of a flexible manufacturing system”, European Journal of Operational Research, Vol. 85 No. 2, pp. 295-315.

Shewan, D. (2017), “Does facebook advertising work?”, available at: www.wordstream.com/blog/ws/ 2016/01/25/does-facebook-advertising-work (accessed 30 September 2018).

Smit, E.G., Van Noort, G. and Voorveld, H.A. (2014), "Understanding online behavioural advertising: user knowledge, privacy concerns and online coping behaviour in Europe", Computers in Human Behavior, Vol. 32, pp. 15-22.

Speck, P.S. and Elliott, M.T. (1997), "Predictors of advertising avoidance in print and broadcast media", Journal of Advertising, Vol. 26 No. 3, p. 61.

Statista (2019a), "Number of social media users worldwide from 2010 to 2021 (in billions)", available at: www.statista.com/statistics/278414/number-of-worldwide-social-network-users/ (accessed 29 November 2019).

Statista (2019b), "Forecast number of mobile users worldwide from 2019 to 2023 (in billions)", available at: www.statista.com/statistics/218984/number-of-global-mobile-users-since-2010/ (accessed 29 November 2019).

Stelzner, M. (2011), "Social media marketing industry report: how marketers are using social media to grow their businesses", available at: www.socialmediaexaminer.com/social-mediamarketingindustry-report-2011 (accessed 29 September 2018).

Stieglitz, S., Mirbabaie, M., Ross, B. and Neuberger, C. (2018), "Social media analytics-challenges in topic discovery, data collection, and data preparation", International Journal of Information Management, Vol. 39, pp. 156-168.

Tam, K.Y. and Ho, S.Y. (2006), "Understanding the impact of web personalization on user information processing and decision outcomes", MIS Quarterly, Vol. 30 No. 4, pp. 865-890.

Tran, T.P. (2017), "Personalized ads on Facebook: an effective marketing tool for online marketers", Journal of Retailing and Consumer Services, Vol. 39, pp. 230-242.

Truong, Y. and Simmons, G. (2010), "Perceived intrusiveness in digital advertising: strategic marketing implications", Journal of Strategic Marketing, Vol. 18 No. 3, pp. 239-256.

Tucker, C.E. (2014), "Social networks, personalized advertising, and privacy controls", Journal of Marketing Research, Vol. 51 No. 5, pp. 546-562. 
SJME

24,2

Wang, T., Oh, L.-B. and Wang, K. (2009), "Antecedents and consequences of mobile advertising intrusiveness", paper presented at the 9th International Conference on Electronic Business Macau, China, 30 November -4 December.

$\mathrm{Xu}$, D.J. (2006), "The influence of personalization in affecting consumer attitude toward mobile advertising in China", Journal Computer Information System, Vol. 47 No. 2, pp. 9-19.

Youn, S. and Shin, W. (2019), "Teens' responses to Facebook newsfeed advertising: the effects of cognitive appraisal and social influence on privacy concerns and coping strategies", Telematics and Informatics, Vol. 38, pp. 30-45.

Yu, J.H. and Cude, B.J. (2009), "Possible disparities in consumers' perceptions toward personalized advertising caused by cultural differences: US and Korea", Journal of International Consumer Marketing, Vol. 21 No. 4, pp. 251-269.

\section{Corresponding author}

Eva Lahuerta-Otero can be contacted at eva.lahuerta@usal.es

For instructions on how to order reprints of this article, please visit our website: 